\title{
Caspase-10 Is the Key Initiator Caspase Involved in Tributyltin-Mediated Apoptosis in Human Immune Cells
}

\author{
Harald F. Krug \\ Department Materials Meet Life, Empa Swiss Federal Laboratories for Materials Science and Technology, Lerchenfeldstrasse 5, \\ 9014 St. Gallen, Switzerland \\ Correspondence should be addressed to Harald F. Krug, Harald.Krug@empa.ch
}

Received 24 May 2011; Accepted 27 September 2011

Academic Editor: Elke Dopp

Copyright ( $) 2012$ Harald F. Krug. This is an open access article distributed under the Creative Commons Attribution License, which permits unrestricted use, distribution, and reproduction in any medium, provided the original work is properly cited.

Tributyltin (TBT) is one of the most toxic compounds produced by man and distributed in the environment. A multitude of toxic activities have been described, for example, immunotoxic, neurotoxic, and endocrine disruptive effects. Moreover, it has been shown for many cell types that they undergo apoptosis after treatment with TBT and the cell death of immune cells could be the molecular background of its immunotoxic effect. As low as $200 \mathrm{nM}$ up to $1 \mu \mathrm{M}$ of TBT induces all signs of apoptosis in Jurkat T cells within 1 to 24 hrs of treatment. When compared to Fas-ligand control stimulation, the same sequence of events occurs: membrane blebbing, phosphatidylserine externalisation, the activation of the "death-inducing signalling complex," and the following sequence of cleavage processes. In genetically modified caspase-8-deficient Jurkat cells, the apoptotic effects are only slightly reduced, whereas, in FADD-negative Jurkat cells, the TBT effect is significantly diminished. We could show that caspase-10 is recruited by the TRAIL-R2 receptor and apoptosis is totally prevented when caspase-10 is specifically inhibited in all three cell lines.

\section{Introduction}

Tributyltin (TBT) is one of the most toxic compounds still used in antifouling paints for large commercial ships thereby distributed within the aquatic environment. Its distribution and accumulation in aquatic organisms leads to severe effects and has already reduced the number of snail species in the near of sea lanes and harbours [1]. Moreover, the trophic transfer has been demonstrated [2], and the accumulation within the food chain up to the level of marine mammals has reached concentrations that might be biological relevant [3-6]. The most prominent biological effect investigated so far is the so-called imposex within sea snails and dogwhelks $[1,7,8]$, and this mechanism is used as biomonitoring tool for organotin compounds [9]. Despite the fact that a lot of studies have been carried out, the underlying molecular mechanism remains unclear $[10,11]$. It has been proposed that the inhibition of aromatase activity alters the ratio of the hormones inducing the development of imposex, the imposition of male sex characteristics on female snails [1, $12]$, but other studies came to other results $[11,13]$.
As organotin compounds were still used and accumulate in the environment as well as in the food chain, the exposure of mammals and humans increases steadily. Moreover, it has been described earlier that organotin compounds, especially TBT, have a clear immunotoxic effect in mammals [1416], and this might be due to their exorbitant induction of apoptosis $[17,18]$. The effective concentration of TBT to induce apoptosis in the majority of treated cells is around or below $1 \mu \mathrm{M}$ and has been shown in vitro [14, 18-27] as well as in vivo $[28,29]$. The question whether the disturbance of the intracellular calcium homeostasis is responsible for the onset of apoptosis [22, 27, 30-34] or the direct effect on mitochondrial functions is the first event $[18,20,24,32,33$, $35]$ is under discussion for a long time. Stridh et al. [18, 23] have shown a decade ago that TBT induces apoptosis via the activation of caspases in various human cells, the link for this caspase activation was not yet found. The most obvious players have been discussed to be the increase in calcium concentration or the opening of the permeability pore of the mitochondria. But induction of apoptosis has been demonstrated for very low concentrations of TBT which 
do not induce calcium influx [27], and caspases are often inhibited by high calcium concentrations [23]. Some years ago, evidence arose that mitochondria-independent mechanisms contribute to the induction of apoptosis and possibly death receptors or direct caspase activation are involved in the TBT induced effect [36-39].

It is now generally accepted that the programmed cell death can be physiologically induced via death receptors on the surface of the cells, activated by specific ligands that are strictly controlled for instance during development or inflammation [40] leading to the formation of the so-called "death-inducing signalling complex" or DISC [41]. Moreover, it has been shown that at least lymphoid cells can be discriminated into type I and type II cells and only type II cells are strongly dependent on functional mitochondria for their apoptotic machinery [42]. Jurkat T-lymphoblastoid cells are type II cells and present a special tool for the investigation of mitochondrial-dependent cell death characteristics. Additionally, genetic modifications of the DISC within these cells enable a closer look at which point the sequence of events is started after TBT-treatment.

In the present study, the mechanism of TBT-induced apoptosis has been investigated by the use of Jurkat Tcells and two variants, caspase- 8 and FADD-deficient Jurkat cells, that provide a direct insight into the death-receptorcoupled mechanisms. The data presented here point to the involvement of initiator caspase activation, especially from caspase-10, and are discussed in terms of the potential immunotoxic role of TBT in exposed mammals.

\section{Results}

2.1. TBT Induces Apoptosis in Human Jurkat Cells. When human immune cells were treated with TBT, changes of morphological as well as biochemical parameters of apoptosis can be observed. In all experiments done in this study, we used $1 \mu \mathrm{M}$ TBT, a concentration that induces apoptosis in the majority of the treated cells within 4 hours. After that, time membrane blebbing and the externalisation of phosphatidylserine (PS) occur and chromatin condensation could be observed in Jurkat A3 T-cells (Figures 1(a) and 1(b)). Chromatin condensation was shown by the use of the DNA dye Hoechst 33342, and PS on the outer leaflet of the plasma membrane is detected with Annexin V-FITC by flow cytometry (FACS) and fluorescence microscopy (Figures $1(\mathrm{c})-1(\mathrm{~h}))$. As demonstrated by two typical FACS dot blots, more than $60 \%$ of the treated cells undergo apoptosis and exhibit green fluorescence at the plasma membrane without being necrotic as the counter staining with propidium iodide demonstrates clearly. Looking closer to the different proteins that are involved in the apoptotic machinery, the complete sequence of events from initiator caspases down to death substrates is switched on. Focussing at the level of initiator caspases, both, caspase- 8 and caspase-10, are cleaved and their active subunits can be detected by western blotting (Figure 1, left). Downstream the initiator caspases, the BID protein is an important linker to the mitochondrial pathway in type II cells and this protein is cleaved after TBT treatment. From the multitude of caspases downstream of the mitochondria we tested for procaspase- $9,-7,-6$, and -3 and found all these proteases cleaved. As one of the most prominent death substrates poly(ADP-ribose) polymerase (PARP) has also been shown to be cleaved within this series of events (Figure 1, left). Moreover, we tested hepatocytes transfected with a fusion protein of cytochrome c/green fluorescent protein (kindly provided by D. Green, La Jolla Institute for Allergy and Immunology, San Diego, USA) and found the release of cytochrome c after TBT treatment (data not shown).

2.2. Apoptosis Is Diminished in Deficient Cell Lines and Dependent from Caspase Activity. The extrinsic pathway upstream the mitochondria is further characterised by use of two genetically modified Jurkat cell lines where one is caspase- 8 deficient and the other is FADD adaptor protein deficient. Furthermore, various caspase inhibitors were used to dissect their roles as possible starting point of the apoptotic sequence of events induced by TBT. Firstly, caspase8 deficient cells exhibit only a slight reduction of apoptosis in all three cell lines when incubated with 1 or $1.5 \mu \mathrm{M}$ TBT (Figure 2), whereas Fas-ligand-induced apoptosis was completely abolished (not shown). Without caspase-8, the only measurable protection was found for PS externalisation that is reduced by one third (Figure 3). Secondly, FADD deficiency affords an improved protection against the effects caused by TBT exposure, especially at lower concentrations (Figure 2, $1 \mu \mathrm{M}$ TBT). This is further corroborated by analysis of PS externalisation and the total caspase activity by a fluorescence assay in living cells. The externalisation of PS was reduced in the same order of magnitude as in the caspase-8-deficient cells (Figure 3), but the CaspaTag assay demonstrates high protease activity in TBT-treated wild-type cells as well as in the caspase-8-deficient variant, whereas in FADD-deficient cells, this activity is obviously reduced (Figure 4).

The importance of caspases for organotin-provoked apoptosis has been investigated by use of several inhibitors. The overall caspase inhibitor zVAD-fmk blocks totally all described effects that normally can be detected after TBT exposure (data not shown). In this study, we used further specific inhibitors of caspases downstream as well as upstream of mitochondria. When caspase- 9 and caspase3 were inhibited as most potent elements of the caspase cascade downstream of the mitochondria, TBT-induced apoptosis is fully prevented in all three cell lines (Figure 2). Preincubation of the Jurkat cells with zLEHD-fmk (caspase-9 inhibitor) and zDEVD-fmk (caspase-3 inhibitor) rescues all viable functions. Nevertheless, a closer look at the western blots revealed often a slight reduction of those elements that were cleaved upstream of the mitochondria, especially BID, even though at slightly higher concentrations of TBT (Figure 2, $1.5 \mu \mathrm{M}$ ). While caspase- 8 is activated in fact after TBT treatment of wild-type Jurkat cells, caspase- 8 deficient cells undergo apoptosis to a comparable extent. This result suggests that caspase- 8 cannot play a substantial role within this concert of effects after TBT treatment. Therefore, we looked closer for caspase-10, the second initiator caspase at the receptor level. 

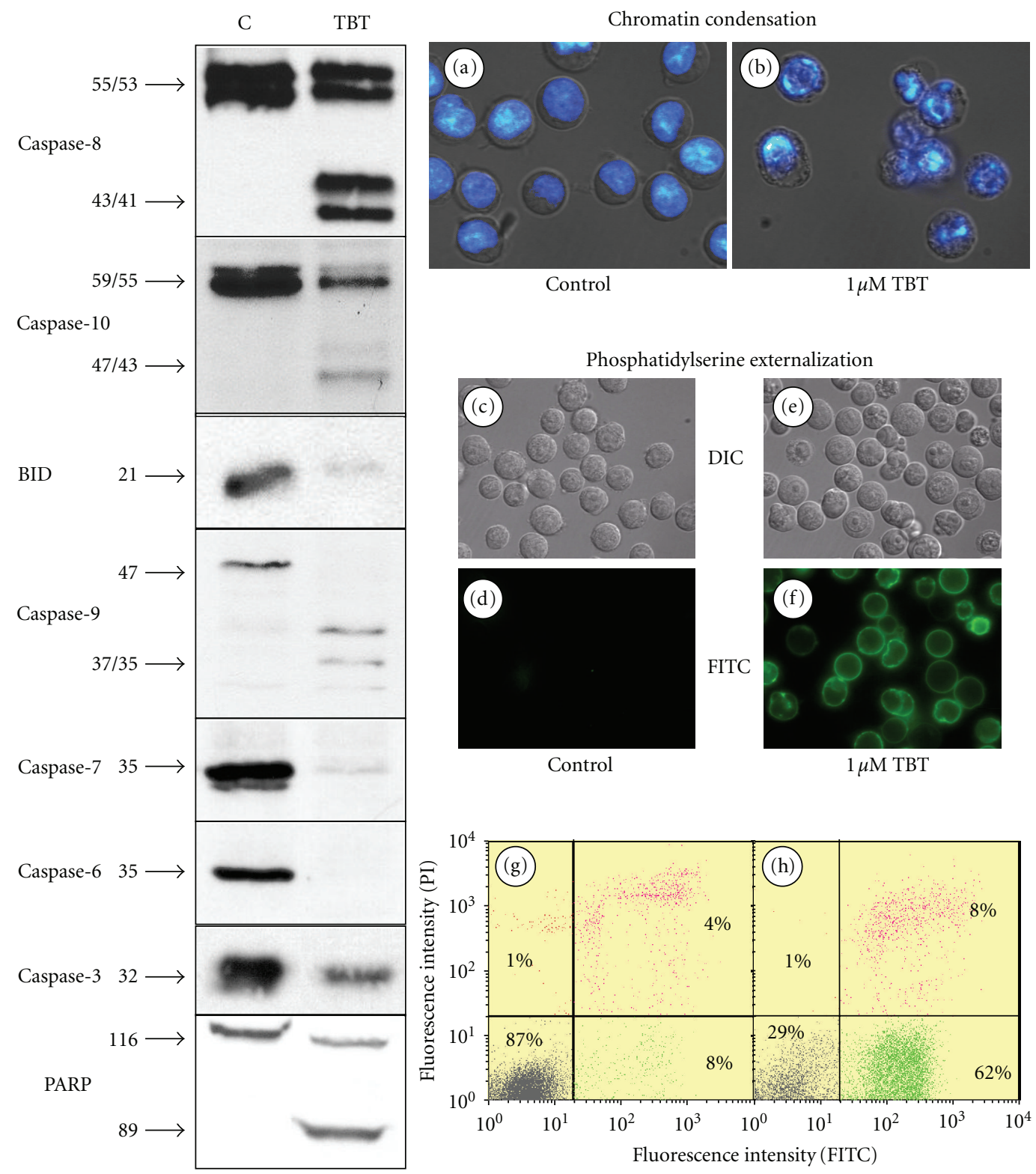

FIgURE 1: Induction of apoptosis in Jurkat T cells by TBT. Jurkat cells were treated with $1 \mu \mathrm{M}$ TBT or ethanol (control) for $4 \mathrm{~h}$ before samples were analysed. Nuclei of vehicle-treated control cells (a) and after TBT treatment (b) were stained with Hoechst 33342 and analysed with a fluorescence microscope. Both pictures show an overlay of differential interference contrast light microscopy pictures with the fluorescence pictures. From the same experiment, samples were stained with annexin V-FITC for phosphatidylserine externalisation (c-h). Control cells were shown with DIC contrast (c), and no green fluorescence could be detected at $525 \pm 12.5 \mathrm{~nm}$ (d). TBT-treated cells exhibit ruffled membranes and granular cytoplasm (e) and strong PS-labelling at the plasma membrane (f). The annexin-positive cells were further quantified by flow cytometry. The quadrant analysis of double labelled cells is shown for control (g) and TBT-treated cells (h). 10000 cells of each sample were counted, and the percentage of viable cells (lower left quadrant, grey dots), apoptotic cells (lower right, green dots), and necrotic cells (upper two quadrants, red dots) were given in the dot blots. On the left side of the figure, immunoblots for 8 different proteins were shown. Protein names and molecular weights are given aside the blots. Left lane: control sample; right lane: TBT-treated sample.

2.3. Caspase-10 Is Obligatory for TBT-Induced Apoptosis, and Its Inhibition Prevents Apoptosis. When caspase-10 is inhibited by zAEVD-fmk, PS externalisation (Figure 3) and overall caspase activity is drastically reduced in all cell lines investigated in this study (Figure 4). Next, we wanted to know if initiator caspases could be found in an activated DISC and which ones. Immunoprecipitations (IP) with an antibody against the Fas-receptor coprecipitated caspase- 8 (data not shown), but this caspase has no substantial relevance for the TBT effect in Jurkat cells as shown above. Therefore, we tested Jurkat cells for other death receptors and found additionally TRAIL-R1, TRAIL-R2, TRAIL-R3, TRAIL-R4, and TNF-R1. As TRAIL-R2 was the dominant form and TRAIL-R3 and TRAIL-R4 are decoy receptors, we 


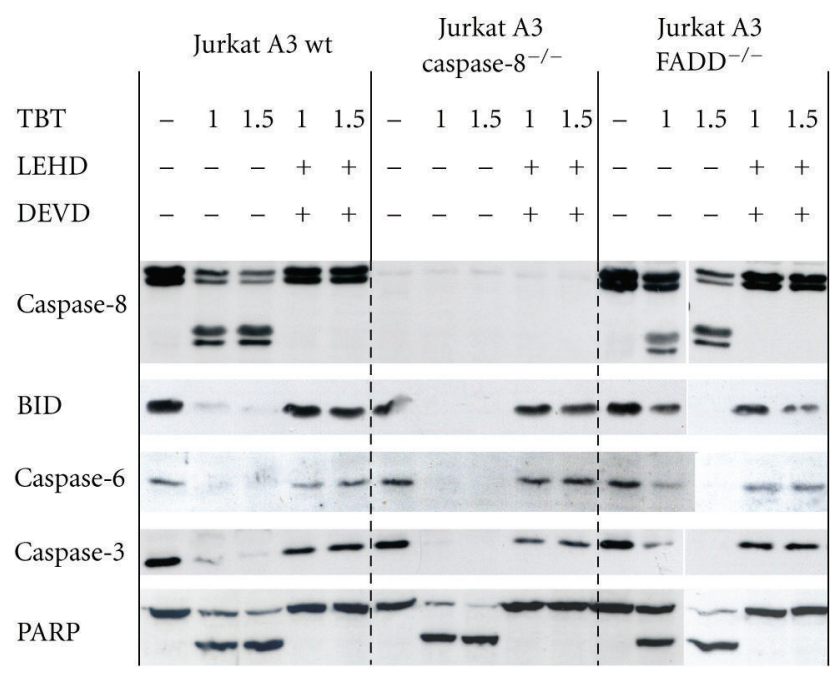

FIgURE 2: Inhibition of TBT-induced apoptosis by caspase-9 and caspase- 3 inhibitors. Western blots of 5 different proteins in Jurkat A3 parental and the two deficient cell lines are shown. Cells were treated with 1 or $1.5 \mu \mathrm{M}$ TBT for $4 \mathrm{~h}$ before proteins were separated on SDS-gels and immunoblotted. Another set of samples was preincubated for $1 \mathrm{~h}$ with the inhibitors for caspase- 3 (DEVD, $10 \mu \mathrm{M})$ and caspase-9 (LEHD, $30 \mu \mathrm{M})$ before TBT $(1 \mu \mathrm{M}$ or $1.5 \mu \mathrm{M}$ ) was added. For molecular weights of proteins and cleavage products, compare Figure 1.

used a TRAIL-R2 antibody for our IPs. With this antibody, we could precipitate both initiator caspases after $3 \mathrm{~h}$ of treatment with $1 \mu \mathrm{M}$ TBT (Figure 5(a)). Additionally, we detected the procaspases- 8 and -10 in the untreated controls but to a much lesser extent and we never found the activated subunits. Analysing the three different cell lines reveals the fact that caspase-10 could be found in all activated DISC forms even though at different levels (Figure 5(b)).

2.4. Different Roles of Caspase- 8 and Caspase-10 in FasLigand and TBT-Induced Apoptosis. A direct comparison of the effects of Fas-ligand and TBT in all three cell lines pretreated with and without the caspase-10 inhibitor zAEVDfmk provides a detailed insight into the different roles of the two initiator caspases in human Jurkat T cells. Fas-ligand treatment of the two deficient cell lines has no effect at all, and, thus, these data were not included in Figure 6. The Jurkat A3 wild-type cells, however, were driven into apoptosis, and this effect is only to a minor degree diminished by the pretreatment with the caspase-10 inhibitor, and apoptosis still proceeds. TBT treatment, however, has approximately the same effect as Fas-ligand in the absence of zAEVD-fmk, but all consequences of this treatment were prevented in the presence of AEVD. Phosphatidylserine externalisation is reduced to nearly control levels (Figure 3 ), and activation of caspases is strongly decreased in all three cell lines (Figure 4). In addition, the cleavage of important caspases is prevented (caspase- 8 and caspase-3, Figure 6), BID cleavage is drastically diminished, PARP is completely rescued, and DNA fragmentation does not proceed anymore (Figure 6).

\section{Discussion}

Trialkylated tin compounds, especially TBT, are distributed all over the environment, and were taken up by cells in vitro fast and effectively and their toxicity is a function of both concentration and duration of exposure [30]. It has long been discussed that this cytotoxicity of organotin compounds might be the result of a massive alteration of the intracellular calcium concentration $\left[\mathrm{Ca}^{2+}\right]_{i}$. Various investigations demonstrated an increase of $\left[\mathrm{Ca}^{2+}\right]_{i}$ after exposure to a variety of trialkytins, and this effect should be responsible for their cytotoxicity, immunotoxicity, and neurotoxicity not only in mammalian $[14,17,30-32]$ but also in fish cell systems [22]. But more and more evidence has been supplied that alteration of $\left[\mathrm{Ca}^{2+}\right]_{i}$ is not the major event in the nonacute cytotoxic scenario $[43,44]$. Numerous studies have been carried out during the last two decades indicating the induction of apoptosis in various biological systems without elucidating the starting point of the involved molecular mechanism $[14,17-25,27,28,36]$. As early as in 2001, the first publication demonstrated a possible involvement of the death receptors [38], and this was confirmed a few years later [37]. Nevertheless, recently published data connect developmental abnormalities of fish larvae with the induction of apoptosis on the level of caspase 3 [45], and the initiating molecular mechanism by which TBT induces apoptosis is not described. Thus, this study was carried out to enlighten the mechanism in more detail.

There exist two different pathways for apoptosis that can be distinguished from each other, the extrinsic and the intrinsic pathway [46]. The intrinsic pathway is dependent from proapoptotic events on the level of the mitochondria and is mostly affected by environmental chemicals or stress factors. Thus, it seems to be obvious that toxic substances such as TBT exert their effect on mitochondria. A multitude of studies have shown that different parameters of mitochondria were altered after treatment of cells with TBT [18, $32,37]$. Nonetheless, the induction of apoptosis could not be explained sufficiently by all these examinations because mitochondria-independent apoptosis has been described as well $[37,47]$ and inhibition of the intrinsic pathway by bcl2 overexpression protects only type II cells but not type I cells from apoptosis although the mitochondrial membrane potential $\Delta \Psi_{m}$ is still high [48]. Moreover, it has been published earlier that various metal compounds may activate the extrinsic apoptotic pathway [37-39, 49]. A closer look on the formation of the "death-inducing signalling complex" (DISC) reveals its formation within 1 to $3 \mathrm{~h}$ after treatment with TBT (Figure 5). Normally, in Jurkat T cells, the DISC consists out of the Fas-receptor molecules to which the adaptor molecules FADD and initiator caspase- 8 are bound. But the caspase-8-deficient Jurkat cells showed no or only little reduction in apoptosis after TBT treatment, and solely FADD deficiency decreases substantially the apoptotic cell number although not all. So we looked for other elements as possible constituents of the DISC. As it was published by several groups that not only caspase- 8 but also caspase- 10 can be recruited to death receptors [50, 51], Apo2L/TRAIL is able to activate both initiator caspases, and caspase- 10 is 


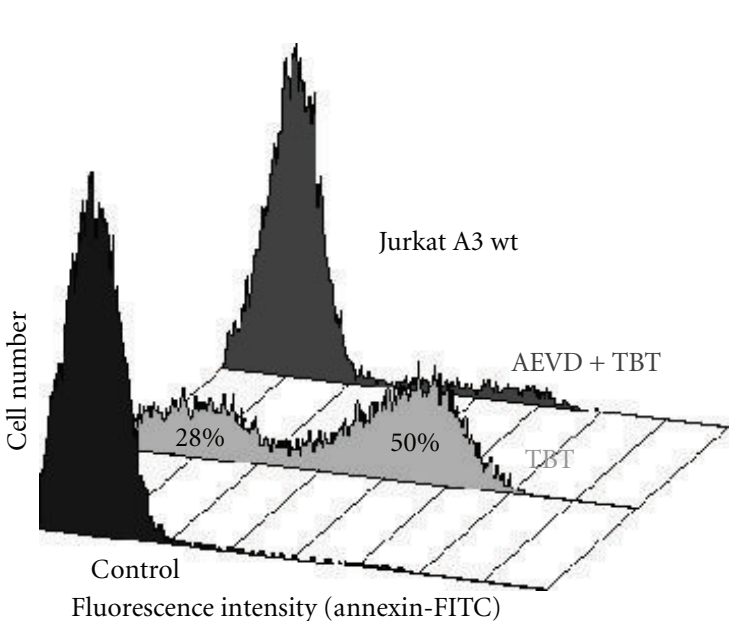

(a)

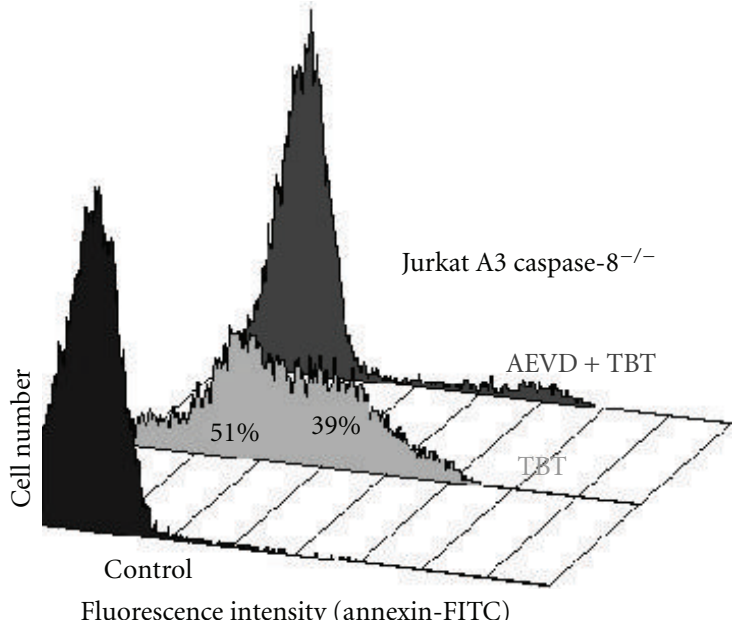

(b)

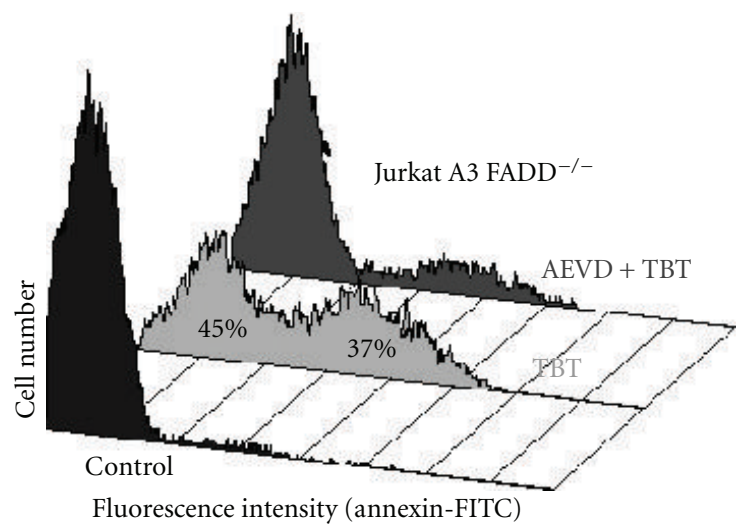

(c)

FIGURE 3: Caspase-10 inhibition prevents TBT-induced apoptosis in all variants of Jurkat A3 cells. Jurkat cells were pretreated with the caspase-10 inhibitor AEVD $(8.7 \mu \mathrm{M}, 1 \mathrm{~h})$ before TBT was added $(1 \mu \mathrm{M}, 4 \mathrm{~h})$. Then, the cells were stained with annexin V-FITC/PI to separate apoptotic cells from necrotic and viable cells by flow cytometry. The histograms show the fluorescence intensity of PI-negative only (compare lower two quadrants in Figures $1(\mathrm{~g})$ and 1(h)). Numbers given for TBT-treated samples represent the percentage of total cells counted (10 000). Presented are the histograms of all three Jurkat A3 variants.

described as important caspase in HCT 116 colon carcinoma cells [52], we analysed the DISC formation in more detail. As mentioned above, caspase-10 could be found in the DISC and is co-precipitated by anti-TRAIL-R2 antibody. These results were confirmed by measuring various caspase activities in lysates using the substrates IETD-pNA (caspase8), AEVD-pNA (caspase-10), and DEVD-pNA (caspase-3), respectively. In lysates of TBT-treated cells, all caspases have been found to be active (data not shown). Thus, TBT leads not only to unspecific cleavage of caspases but directly to their activation.

Because caspase-8-deficient Jurkat cells express lower amounts of caspase-10 compared to their parental cell line, these cells might be somewhat less sensitive to TBT as demonstrated here (Figure 3). But determination of all apoptotic markers revealed a nearly unchanged sensitivity to TBT of Jurkat cells lacking caspase- 8 when treatment is prolonged to a minimum of $4 \mathrm{~h}$. Another set of experiments focuses on caspases in more detail. Overall inhibition of caspases with
zVAD-fmk, an unspecific inhibitor of all cellular caspases, inhibits totally TBT-induced apoptosis in human neutrophils [19] as well as in Jurkat cells (data not shown). A strong evidence for a specific role of the initiator caspase-10 comes from our experiments with its specific inhibitor zAEVDfmk. While Fas-ligand-induced apoptosis is only slightly prevented after pre-incubation of the cells with AEVD (Figure 6), TBT-treatment has no effect at all, when caspase10 was inactivated before. Nevertheless, Kischkel and coworkers [50] described FADD as an obligatory adaptor for both initiator caspases to TRAIL receptor; thus, we expected the FADD-deficient cells to be protected against TBTinduced apoptosis. But this is the case only for lower concentrations of TBT up to $1 \mu \mathrm{M}$. In this case, the prevention of FADD-deficient cells is apparent (Figure 2), whereas slightly higher concentrations $(1.5 \mu \mathrm{M})$ overcome this protective effect. This might be due to the fact that these higher concentrations directly affect, on the one hand, the intrinsic machinery of apoptosis or, on the other hand, TBT might be 


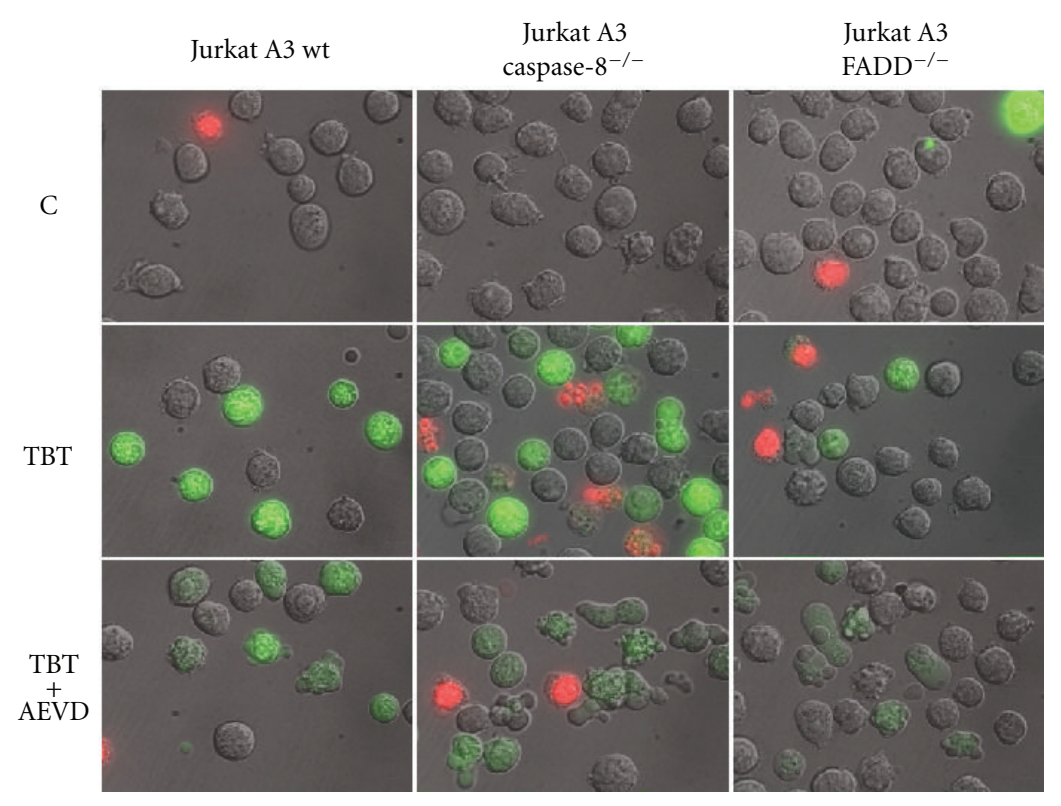

FIGURE 4: Caspase activity induced by TBT treatment in Jurkat A3 cells. Jurkat cells were pretreated with the caspase-10 inhibitor AEVD $(8.7 \mu \mathrm{M}, 1 \mathrm{~h})$ before TBT was added $(1 \mu \mathrm{M}, 4 \mathrm{~h})$. At the end of the treatment, FAM-VAD-fmk was added as a caspase substrate that exhibits fluorescence after cleavage. Cells were incubated for further $60 \mathrm{~min}$, counterstained with propidium iodide (red fluorescence), and intracellular fluorescence intensity was analysed by microscopy. C: vehicle-treated control cells; TBT: $1 \mu \mathrm{M}$ TBT; TBT + AEVD: pretreated with zAEVD-fmk for $1 \mathrm{~h}$ and $1 \mu \mathrm{M}$ TBT for further $4 \mathrm{~h}$.

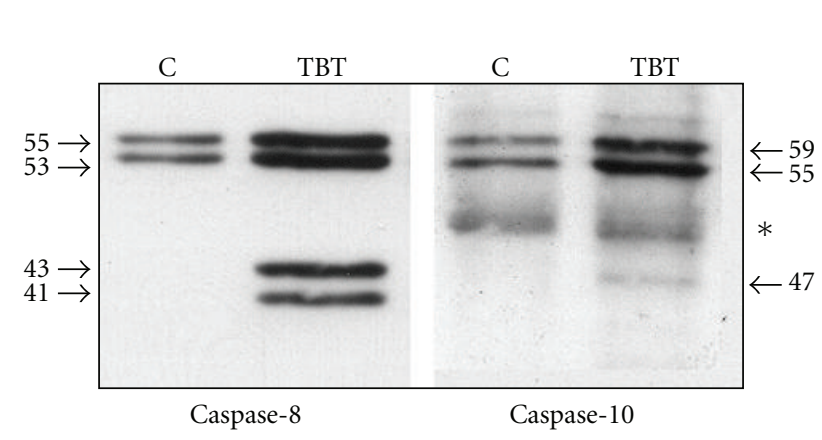

(a)

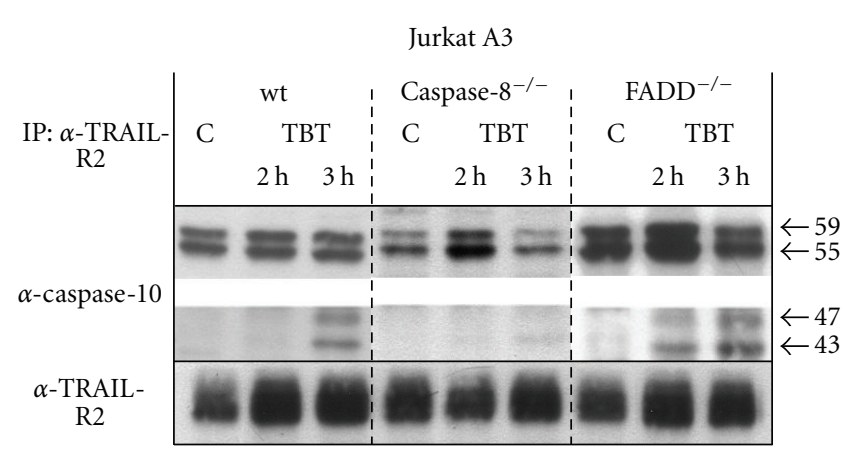

(b)

FIgURE 5: TBT induces recruitment of caspase- 8 and caspase-10 by TRAIL-R2. Jurkat A3 wt cells were treated with or without TBT for $3 \mathrm{~h}$ before cells were lysed and immunoprecipitation (IP) was carried out with anti-TRAIL-R2 antibody. Initiator caspase- 8 and caspase-10 were detected by western blotting (WB) in the precipitates (a). Both antibodies recognise full length procaspases and the processed subunits. Asterisk indicates an unspecific band. Caspase-10 was further investigated in all three cell lines after IP with anti-TRAIL-R2 antibody (b). After 2 or $3 \mathrm{~h}$ of incubation with TBT, cells were analysed by IP/WB. In all three cell lines, the amount of procaspase-10 and/or its cleavage products increase over time in the precipitate. Loading control for TRAIL-R2 is shown below. Arrows and numbers give the molecular weight of procaspases and cleaved subunits. Both parts of the western blot (upper part containing the procaspase-10, lower part with the cleavage products) are differentially exposed to visualize the weak bands of the cleavage products.

able to activate directly caspases as has been demonstrated earlier [36, 47]. Another evidence for caspase-10 dependency with no or only less involvement of FADD-adaptor protein has been described recently for another chemical but with the same set of Jurkat cells [53]. This group found the same total inhibition of all effects by the caspase-10 inhibitor zAEVDfmk and no reduction in caspase-8-deficient cells. Moreover, FADD recruitment was not involved because the FADDdeficient Jurkat cells exhibited DNA fragmentation and other signs of apoptosis; thus, these results are obviously congruent with the data presented here.

Furthermore, it has been published lately that caspase10 may cleave specific substrates, as the proapoptotic protein BID, without being cleaved before into its active subunits [54]. This may be the reason why type II cells are more sensitive to bcl-2 overexpression than type I cells, as type II cells are dependent on BID cleavage and the activation of the mitochondrial pathway. In our hands, the type I cell line 


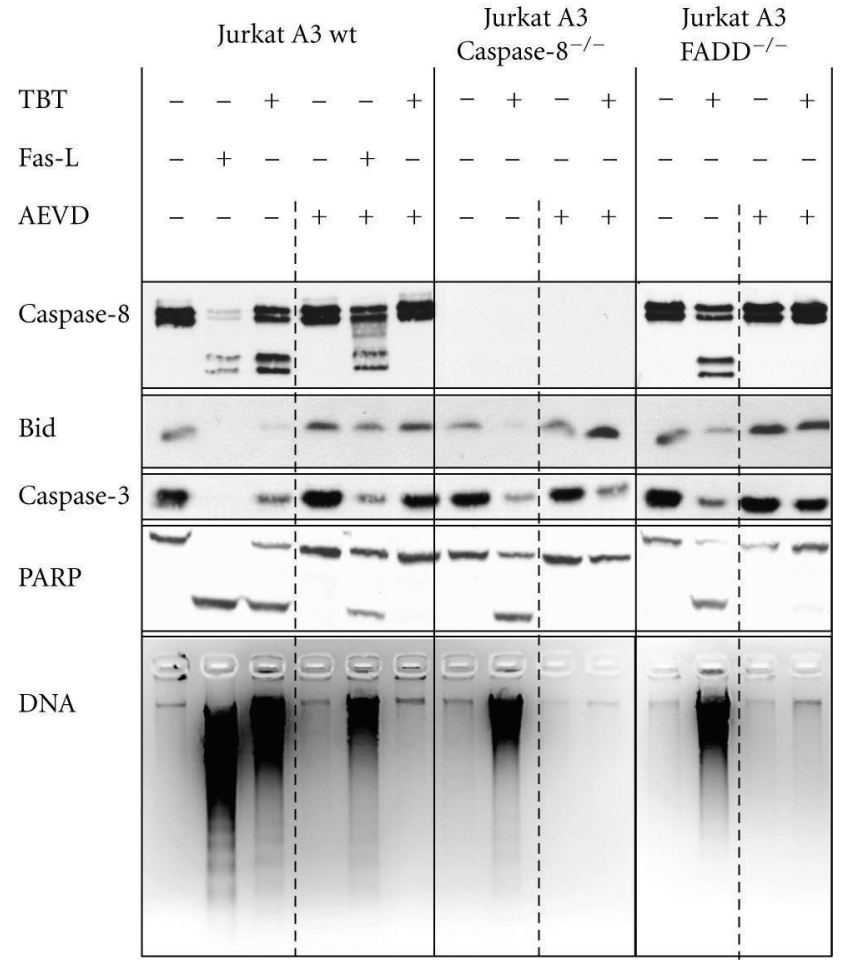

Figure 6: Caspase-10 inhibition prevents all TBT-induced apoptotic effects in Jurkat A3 cells. Jurkat A3 parental and the two deficient cell lines were analysed as shown in Figure 2 except the pretreatment was accomplished with zAEVD-fmk. Jurkat A3 wt cells were treated with $1 \mu \mathrm{M}$ TBT or Fas-ligand (Fas-L) as positive control for $4 \mathrm{~h}$, and the deficient cell lines were treated with TBT only before proteins were separated on SDS-gels and immunoblotted. A second set of samples was preincubated for $1 \mathrm{~h}$ with the caspase-10 inhibitor AEVD $(8.7 \mu \mathrm{M})$ before TBT or Fas-L were added. Additionally, DNA fragmentation was recorded from the same samples after agarose gel electrophoresis.

SKW has a higher level of caspase-10 expression, and this is cleaved at the DISC in both variants, the wild type as well as in the bcl-2 overexpressing line (data not shown).

The question to what extent the extrinsic or the intrinsic pathway is responsible for the TBT-induced apoptosis in the absence of a functional FADD adaptor protein can be answered by the concentrations of TBT used within the experiments. Lower concentrations not disturbing the lysosomal or mitochondrial systems are more or less totally dependent on the formation of an activated DISC, whereas higher concentrations overcome this mechanism and stress the intracellular machinery via lysosomes or/and mitochondria leading to caspase-independent responses [55-57]. The here described results indicate that TBT in principle activates initiator caspase-10 leading to BID cleavage and activation of the mitochondria inducing the downstream apoptotic machinery (Figure 7).

Besides mammalian system cells from other species were affected by TBT as well. In trout blood cells, $1-5 \mu \mathrm{M}$ TBT induces apoptosis within $1 \mathrm{~h}$ [35], and, in gill tissue of the mussel Mytilus galloprovincialis treated with $1 \mu \mathrm{g} / \mathrm{g}$ bw TBT $(\approx 3 \mu \mathrm{M})$, apoptosis could be detected after $24 \mathrm{~h}$ incubation [28]. The strongly discussed immunosuppressive properties of TBT in vivo might be the consequence of specific induction of cell death in immunocompetent cells. Such a killing of lymphocytes by TBT can be observed as a loss in thymus weight or thymus atrophy $[29,58]$ that debilitates the immune function of animals, making them vulnerable to infectious diseases [59-63].

On the background of these findings, the deadline for banning TBT must be possibly reconsidered as not only sea snails but also open water mammals and humans might be affected and new regulatory strategies have to be discussed independent from market forces [64]. Whereas the International Maritime Organisation (IMO) has banned TBT since 2008, the European Commission has forbidden its use "after 1st of July 2010 in articles where the concentration in the article, or part thereof, is greater than the equivalent of $0.1 \%$ by weight of tin," but "articles treated with such biocides may still be imported into the Community" [65].

\section{Materials and Methods}

4.1. Materials. All cell culture reagents were purchased from Life Technologies (Eggenstein, Germany), petri dishes and multiwell plates were obtained from Nunc (Wiesbaden, Germany). Annexin-FITC is from BD Pharmingen (Heidelberg, Germany), PI and Hoechst 33342 from Sigma (Deisenhofen, Germany), and the inhibitors of caspase-10 (zAEVD-fmk; FMK009), caspase-9 (zLEHD-fmk; FMK008), and caspase3 (zDEVD-fmk; FMK004) were from R\&D Systems (Wiesbaden, Germany).

The primary antibodies anti-caspase-6 (Cat no. 9762), anti-caspase-7 (Cat no. 9492) and anti-caspase-9 (Cat no. 9502) were purchased from Cell Signaling Technology (Frankfurt, Germany), anti-caspase-3 (Cat no. C31720), and anti-caspase-8 (Cat no. 551242 clone 3-1-9) from BD Pharmingen (Heidelberg, Germany), anti-caspase-10/a (Cat no. M059-3) from MoBiTec (MBL) (Göttingen, Germany), anti-TRAIL-R2 (DR5) (Cat no. PC392) from Calbiochem (Darmstadt, Germany), anti-BID (Cat no. AF846) from R\&D Systems (Wiesbaden, Germany), and anti-PARP (Cat no. 1835238) from Roche Biochemica (Mannheim, Germany). As secondary reagents, we used: horseradish-peroxidase(HRP-) conjugated goat anti-mouse IgG1 (Cat no. P 0447) from DakoCytomation (Glostrup, Denmark) and HRP-conjugated donkey anti-rabbit (Cat no. NA934) from Amersham Biosciences (Freiburg, Germany).

4.2. Cell Cultures. The Jurkat cell line A3 as well as the FADD and caspase-8-deficient cell lines were kindly provided by J. Blenis (Harvard Medical School, Boston, USA) and were maintained in RPMI 1640 supplemented with 10\% FCS and $1 \mathrm{mM}$ HEPES. The cultures were grown with $100 \mathrm{U} / \mathrm{mL}$ penicillin and $100 \mu \mathrm{g} / \mathrm{mL}$ streptomycin in a humidified atmosphere containing $5 \% \mathrm{CO}_{2}$ at $37^{\circ} \mathrm{C}$. During experiments, $10 \mathrm{mM}$ glucose were additionally included in the incubation medium. 


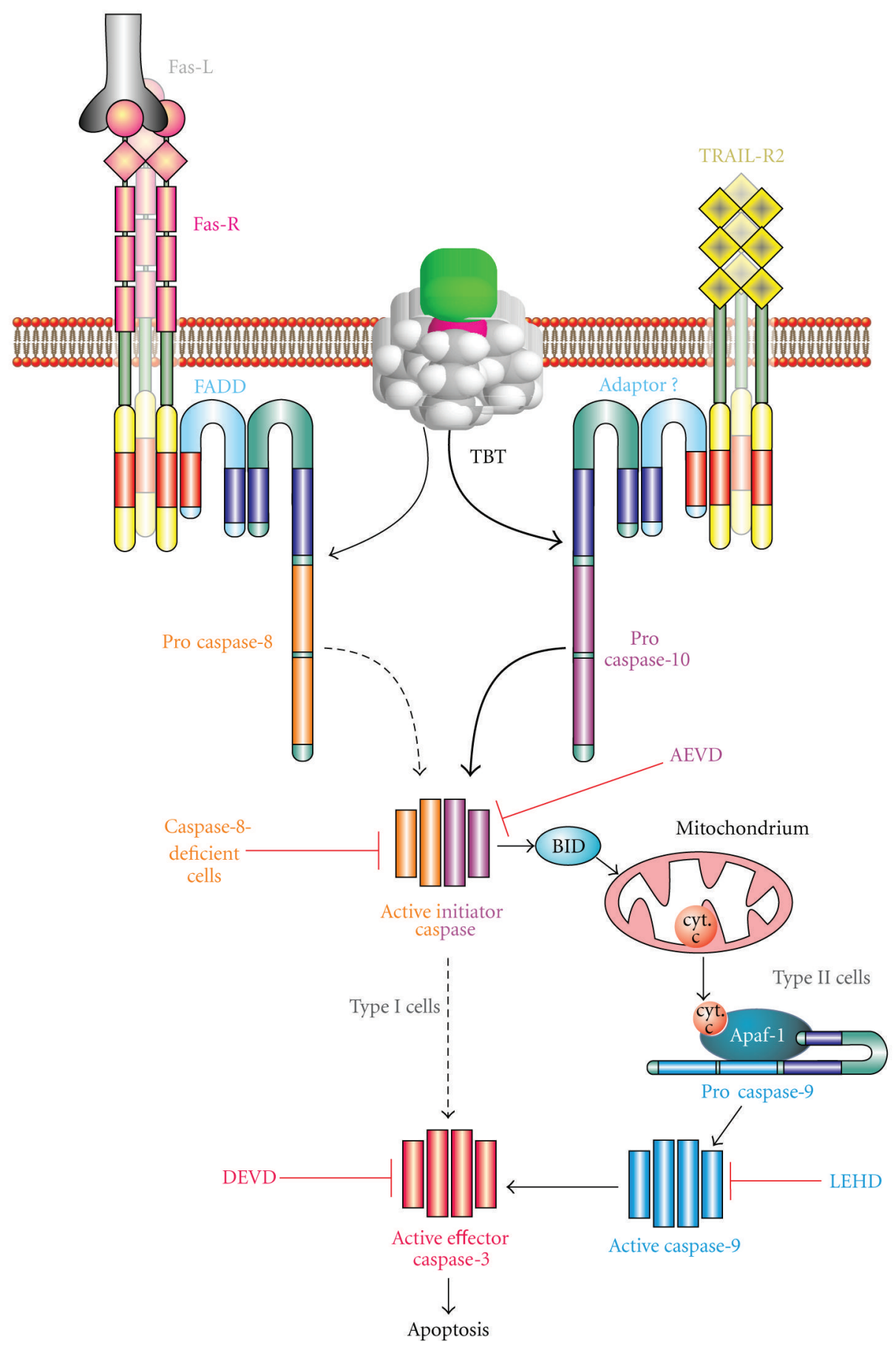

FIgURE 7: Proposed scheme of TBT-induced apoptosis in Jurkat cells. TBT activates caspase-10 upstream of mitochondria which leads to BID cleavage, and activation of the mitochondria. Downstream caspases were then cleaved and the caspase-cascade is provoked. Caspase- 8 deficiency cannot prevent apoptosis, but inhibition of caspase-10 (AEVD) or inhibition of the two important caspases downstream of the mitochondria, caspase-9 and caspase-3 (LEHD and DEVD), totally suppress cell death.

\subsection{Methods}

4.3.1. Treatment of the Cells. For induction of apoptosis, $2 \times$ $10^{6}$ cells per $\mathrm{mL}$ medium were incubated with $1 \mu \mathrm{L} / \mathrm{mL}$ of a $1 \mathrm{mM}$ stock solution of TBT (Merck) in ethanol to give the final concentration of $1 \mu \mathrm{M}$. As a positive control, $100 \mathrm{ng}$ Fasligand plus $1 \mu \mathrm{g}$ enhancer (Alexis, San Diego, USA) per $\mathrm{mL}$ incubation medium were used. All controls were incubated 
with the same amount of vehicle $(1 \mu \mathrm{L}$ ethanol $/ \mathrm{mL})$ to exclude side effects of the solvent.

4.3.2. DNA Fragmentation. Apoptotic DNA fragments were isolated according to the following procedure. $2 \times 10^{6}$ were disrupted in $500 \mu \mathrm{L}$ lysis buffer (20 mM EDTA, $1 \%$ NP 40, $50 \mathrm{mM}$ Tris/HCl, pH 7.5). After centrifugation at $1600 \mathrm{~g}$ for $5 \mathrm{~min}$, supernatants containing the apoptotic DNA were transferred into Eppendorf tubes. After addition of 1\% SDS, samples were treated for $2 \mathrm{~h}$ with RNAse-A $(5 \mu \mathrm{g} / \mu \mathrm{L})$ at $56^{\circ} \mathrm{C}$ and subsequently for further $2 \mathrm{~h}$ with proteinase $\mathrm{K}$ $(2.5 \mu \mathrm{g} / \mu \mathrm{L})$. The DNA was precipitated by the addition of $50 \mu \mathrm{L}$ of $10 \mathrm{M}$ ammoniumacetate and $250 \mu \mathrm{L}$ ice-cold ethanol, stored overnight at $-20^{\circ} \mathrm{C}$ followed by centrifugation. The pellet was resuspended in $25 \mu \mathrm{L}$ of TE-buffer $(10 \mathrm{mM}$ Tris/HCl, $1 \mathrm{mM}$ EDTA, $\mathrm{pH} 8.0$ ), and the DNA-fragments were analysed by agarose gel electrophoresis $(1.8 \%$ agarose containing ethidium bromide as DNA stain), and pictures were taken with a MWG Gel documentation system.

4.3.3. Caspa-Tag Assay. The assay was carried out as described by the manufacturer (Intergen, Heidelberg, Germany). From each treated sample, $150 \mu \mathrm{L}$ containing $3 \times$ $10^{5}$ cells were washed with fresh medium and $10 \mu \mathrm{L}$ of $30 \mathrm{x}$ solution of the caspase substrate FAM-VAD-fmk were added to give the final concentration of $10 \mu \mathrm{M}$. The mixture was further incubated for $1 \mathrm{~h}$ in an incubator at $37^{\circ} \mathrm{C}$. Then, $1 \mathrm{~mL}$ of washing solution was added, the suspension was centrifuged at $400 \mathrm{~g}$ for $5 \mathrm{~min}$ at room temperature. The resulting cell pellet was washed once with washing buffer and finally resuspended in $400 \mu \mathrm{L}$ washing buffer including $1 \mu \mathrm{L}$ PI as counterstain for necrosis. Cells were left for $15 \mathrm{~min}$ on ice, and then the microscopic pictures were taken.

4.3.4. Immunoprecipitation. TRAIL-associated caspase- 10 and caspase- 8 were immunoprecipitated as follows: $10^{7}$ cells $\left(2 \times 10^{6} / \mathrm{mL}\right)$ were treated with $1 \mu \mathrm{M}$ TBT and then lysed in $500 \mu \mathrm{L}$ cell lysis buffer $(30 \mathrm{mM}$ Tris/ $\mathrm{HCl}, \mathrm{pH}$ 7.5, $150 \mathrm{mM} \mathrm{NaCl}, 1 \mathrm{mM}$ phenylmethylsulfonyl fluoride, $10 \mu \mathrm{g} / \mathrm{mL}$ aprotinin and $10 \mu \mathrm{g} / \mathrm{mL}$ leupeptin, $1 \%$ Triton and $10 \%$ glycerol). The lysates were centrifuged at $14000 \mathrm{~g}$ for $10 \mathrm{~min}$ at $4^{\circ} \mathrm{C}$. The supernatants were then incubated for $4 \mathrm{~h}$ with protein A-Sepharose (Sigma, Deisenhofen, Germany) and $1.5 \mu \mathrm{g}$ anti-TRAIL-R2. The beads were centrifuged at $7000 \mathrm{~g}$ for $6 \mathrm{~min}$ at $4^{\circ} \mathrm{C}$, washed once with the same amount of lysis buffer, and centrifuged again. After having removed the supernatants carefully, the pellets were resuspended in $100 \mu \mathrm{L}$ electrophoresis buffer and $15 \mu \mathrm{L}$ of each sample were analysed by SDS-gel electrophoresis and western blotting.

4.3.5. Apoptosis Assays. Apoptotic and necrotic cells were determined either microscopically or by flow cytometry using recombinant annexin $\mathrm{V}$ conjugated to FITC and propidium iodide. The determination of apoptosis is based on the binding of annexin V-FITC on the phosphatidylserine exposed at the surface of apoptotic cells. Necroses were determined by staining with the membrane impermeable DNA-intercalating dye PI. For the assay, $1 \times 10^{6}$ cells were pelleted at $1500 \mathrm{~g}$ and resuspended in $100 \mu \mathrm{L}$ binding buffer ( $10 \mathrm{mM}$ HEPES, pH 7.4, $140 \mathrm{mM} \mathrm{NaCl}$ and $5 \mathrm{mM} \mathrm{CaCl}_{2}$ ) containing $5 \mu \mathrm{L}$ annexin V-FITC and $100 \mathrm{ng}$ PI. After $15 \mathrm{~min}$ of incubation at $4^{\circ} \mathrm{C}$ in the dark, cells were diluted in $400 \mu \mathrm{L}$ binding buffer and immediately analysed by flow cytometry. Fluorescence was analysed at $530 \pm 14 \mathrm{~nm}$ (FITC) and $610 \pm 10 \mathrm{~nm}$ (PI) and quantified with the CELLQuest Prosoftware (BD, Heidelberg, Germany).

For microscopic assessment of apoptosis and necrosis, 6 $\times 10^{4}$ cells were diluted $1: 1$ with $2 x$ binding buffer, containing $1 \mu \mathrm{L}$ annexin V-FITC and $3 \mathrm{ng}$ PI. After 15 min of incubation in the dark, cells were analysed with a $63 \mathrm{x}$ oil objective and a Zeiss Axiovert S100 microscope (Carl Zeiss $\mathrm{GmbH}$, Jena, Germany), connected to a Hamamatsu CCD Camera (C4880-80). Fluorescence and differential interference contrast pictures were taken using an automation procedure and merged using Openlab software (Improvision, Coventry, UK).

Chromatin condensation was determined after staining of the cells with Hoechst 33342 . In short, after treatment, $1 \times$ $10^{6}$ cells were washed with phosphate-buffered saline (PBS) incubated with a final concentration of $10 \mu \mathrm{M}$ Hoechst 33342 for $10 \mathrm{~min}$, washed again with PBS to reduce background fluorescence, and finally visualised with the same system described above with excitation at $364 \pm 15 \mathrm{~nm}$ and emission at $460 \pm 10 \mathrm{~nm}$.

\section{Acknowledgments}

The author thanks Dr. John Blenis for providing the genetically modified Jurkat cells. He is grateful to Dorit Mattern and Silvia Meixner for their excellent technical assistance. This work was partially supported by grants of the Karlsruhe Institute of Technology (formerly, Research Centre Karlsruhe).

\section{References}

[1] J. Oehlmann, B. Markert, E. Stroben, U. Schulte-Oehlmann, B. Bauer, and P. Fioroni, "Tributyltin biomonitoring using prosobranchs as sentinel organisms," Analytical and Bioanalytical Chemistry, vol. 354, no. 5-6, pp. 540-545, 1996.

[2] K. Békri and É. Pelletier, "Trophic transfer and in vivo immunotoxicological effects of tributyltin (TBT) in polar seastar Leptasterias polaris," Aquatic Toxicology, vol. 66, no. 1, pp. 3953, 2004.

[3] J. A. Berge, E. M. Brevik, A. Bjørge, N. Følsvik, G. W. Gabrielsen, and H. Wolkers, "Organotins in marine mammals and seabirds from Norwegian territory," Journal of Environmental Monitoring, vol. 6, no. 2, pp. 108-112, 2004.

[4] T. Ciesielski, A. Wasik, I. Kuklik, K. Skóra, J. Namieśnik, and P. Szefer, "Organotin compounds in the liver tissue of marine mammals from the Polish coast of the Baltic Sea," Environmental Science and Technology, vol. 38, no. 5, pp. 14151420, 2004.

[5] H. Iwata, S. Tanabe, T. Mizuno, and R. Tatsukawa, "Bioaccumulation of butyltin compounds in marine mammals: the specific tissue distribution and composition," Applied Organometallic Chemistry, vol. 11, no. 4, pp. 257-264, 1997.

[6] H. Nakata, A. Sakakibara, M. Kanoh et al., "Evaluation of mitogen-induced responses in marine mammal and human 
lymphocytes by in-vitro exposure of butyltins and non-ortho coplanar PCBs," Environmental Pollution, vol. 120, no. 2, pp. 245-253, 2002.

[7] N. Følsvik, J. A. Berge, E. M. Brevik, and M. Walday, "Quantification of organotin compounds and determination of imposex in populations of dogwhelks (Nucella lapillus) from Norway," Chemosphere, vol. 38, no. 3, pp. 681-691, 1999.

[8] U. Schulte-Oehlmann, M. Tillmann, B. Markert, J. Oehlmann, B. Watermann, and S. Scherf, "Effects of endocrine disruptors on prosobranch snails (mollusca: gastropoda) in the laboratory. Part II: triphenyltin as a xeno-androgen," Ecotoxicology, vol. 9, no. 6, pp. 399-412, 2000.

[9] V. Axiak, D. Micallef, J. Muscat, A. Vella, and B. Mintoff, "Imposex as a biomonitoring tool for marine pollution by tributyltin: some further observations," Environment International, vol. 28, no. 8, pp. 743-749, 2003.

[10] Y. Yamabe, A. Hoshino, N. Imura, T. Suzuki, and S. Himeno, "Enhancement of androgen-dependent transcription and cell proliferation by tributyltin and triphenyltin in human prostate cancer cells," Toxicology and Applied Pharmacology, vol. 169, no. 2, pp. 177-184, 2000.

[11] E. Oberdörster and P. McClellan-Green, "Mechanisms of imposex induction in the mud snail, Ilyanassa obsoleta: TBT as a neurotoxin and aromatase inhibitor," Marine Environmental Research, vol. 54, no. 3-5, pp. 715-718, 2002.

[12] M. M. Santos, C. C. Ten Hallers-Tjabbes, N. Vieira, J. P. Boon, and C. Porte, "Cytochrome P450 differences in normal and imposex-affected female whelk Buccinum undatum from the open North Sea," Marine Environmental Research, vol. 54, no. 3-5, pp. 661-665, 2002.

[13] Y. Morcillo and C. Porte, "Evidence of endocrine disruption in the imposex-affected gastropod Bolinus brandaris," Environmental Research, vol. 81, no. 4, pp. 349-354, 1999.

[14] T. Y. Aw, P. Nicotera, L. Manzo, and S. Orrenius, "Tributyltin stimulates apoptosis in rat thymocytes," Archives of Biochemistry and Biophysics, vol. 283, no. 1, pp. 46-50, 1990.

[15] N. J. Snoeij, A. H. Penninks, and W. Seinen, "Dibutyltin and tributyltin compounds induce thymus atrophy in rats due to a selective action on thymic lymphoblasts," International Journal of Immunopharmacology, vol. 10, no. 7, pp. 891-899, 1988.

[16] J. G. Vos and E. I. Krajnc, "Immunotoxicity of pesticides," Developments in Toxicology and Environmental Science, vol. 11, pp. 229-240, 1983.

[17] S. Orrenius, M. J. McCabe, and P. Nicotera, " $\mathrm{Ca}^{2+}$-dependent mechanisms of cytotoxicity and programmed cell death," Toxicology Letters, vol. 64-65, pp. 357-364, 1992.

[18] H. Stridh, M. Kimland, D. P. Jones, S. Orrenius, and M. B. Hampton, "Cytochrome c release and caspase activation in hydrogen peroxide- and tributyltin-induced apoptosis," FEBS Letters, vol. 429, no. 3, pp. 351-355, 1998.

[19] V. Lavastre and D. Girard, "Tributyltin induces human neutrophil apoptosis and selective degradation of cytoskeletal proteins by caspases," Journal of Toxicology and Environmental Health Part A, vol. 65, no. 14, pp. 1013-1024, 2002.

[20] A. Nishikimi, Y. Kira, E. Kasahara et al., "Tributyltin interacts with mitochondria and induces cytochrome c release," Biochemical Journal, vol. 356, no. 2, pp. 621-626, 2001.

[21] M. Raffray, D. McCarthy, R. T. Snowden, and G. M. Cohen, "Apoptosis as a mechanism of tributyltin cytotoxicity to thymocytes: relationship of apoptotic markers to biochemical and cellular effects," Toxicology and Applied Pharmacology, vol. 119, no. 1, pp. 122-130, 1993.

[22] S. Reader, V. Moutardier, and F. Denizeau, "Tributyltin triggers apoptosis in trout hepatocytes: the role of $\mathrm{Ca}^{2+}$, protein kinase C and proteases," Biochimica et Biophysica Acta, vol. 1448, no. 3, pp. 473-485, 1999.

[23] H. Stridh, S. Orrenius, and M. B. Hampton, "Caspase involvement in the induction of apoptosis by the environmental toxicants tributyltin and triphenyltin," Toxicology and Applied Pharmacology, vol. 156, no. 2, pp. 141-146, 1999.

[24] H. Stridh, I. Cotgreave, M. Müller, S. Orrenius, and D. Gigliotti, "Organotin-induced caspase activation and apoptosis in human peripheral blood lymphocytes," Chemical Research in Toxicology, vol. 14, no. 7, pp. 791-798, 2001.

[25] O. Yamanoshita, M. Kurasaki, T. Saito et al., "Diverse effect of tributyltin on apoptosis in PC12 cells," Biochemical and Biophysical Research Communications, vol. 272, no. 2, pp. 557$562,2000$.

[26] C. Umebayashi, Y. Oyama, L. Chikahisa-Muramastu et al., "Tri-n-butyltin-induced cytotoxicity on rat thymocytes in presence and absence of serum," Toxicology in Vitro, vol. 18, no. 1, pp. 55-61, 2004.

[27] F. Zaucke, H. Zöltzer, and H. F. Krug, "Dose-dependent induction of apoptosis or necrosis in human cells by organotin compounds," Fresenius' Journal of Analytical Chemistry, vol. 361, no. 4, pp. 386-392, 1998.

[28] M. Mičić, N. Bihari, Ž. Labura, W. E. G. Müller, and R. Batel, "Induction of apoptosis in the blue mussel Mytilus galloprovincialis by tri-n-butyltin chloride," Aquatic Toxicology, vol. 55, no. 1-2, pp. 61-73, 2001.

[29] M. Raffray and G. M. Cohen, "Thymocyte apoptosis as a mechanism for tributylin-induced thymic atrophy in vivo," Archives of Toxicology, vol. 67, no. 4, pp. 231-236, 1993.

[30] T. Ade, F. Zaucke, and H. F. Krug, "The structure of organometals determines cytotoxicity and alteration of calcium homeostasis in HL-60 cells," Fresenius' Journal of Analytical Chemistry, vol. 354, no. 5-6, pp. 609-614, 1996.

[31] S. C. Chow, G. E. N. Kass, M. J. McCabe, and S. Orrenius, "Tributyltin increases cytosolic free $\mathrm{Ca}^{2+}$ concentration in thymocytes by mobilizing intracellular $\mathrm{Ca}^{2+}$, activating a $\mathrm{Ca}^{2+}$ entry pathway, and inhibiting $\mathrm{Ca}^{2+}$ efflux," Archives of Biochemistry and Biophysics, vol. 298, no. 1, pp. 143-149, 1992.

[32] A. Gennari, B. Viviani, C. L. Galli, M. Marinovich, R. Pieters, and E. Corsini, "Organotins induce apoptosis by disturbance of $\left[\mathrm{Ca}^{2+}\right]_{\mathrm{i}}$ and mitochondrial activity, causing oxidative stress and activation of caspases in rat thymocytes," Toxicology and Applied Pharmacology, vol. 169, no. 2, pp. 185-190, 2000.

[33] H. Stridh, D. Gigliotti, S. Orrenius, and I. Cotgreave, "The role of calcium in pre- and postmitochondrial events in tributyltin-induced T-cell apoptosis," Biochemical and Biophysical Research Communications, vol. 266, no. 2, pp. 460-465, 1999.

[34] B. Viviani, A. D. Rossi, S. C. Chow, and P. Nicotera, "Organotin compounds induce calcium overload and apoptosis in PC12 cells," NeuroToxicology, vol. 16, no. 1, pp. 19-25, 1995.

[35] L. Tiano, D. Fedeli, G. Santoni, I. Davies, and G. Falcioni, "Effect of tributyltin on trout blood cells: changes in mitochondrial morphology and functionality," Biochimica et Biophysica Acta, vol. 1640, no. 2-3, pp. 105-112, 2003.

[36] C. P. Berg, A. Rothbart, K. Lauber et al., "Tributyltin (TBT) induces ultra-rapid caspase activation independent of apoptosome formation in human platelets," Oncogene, vol. 22, no. 5, pp. 775-780, 2003.

[37] M. Jurkiewicz, D. A. Averill-Bates, M. Marion, and F. Denizeau, "Involvement of mitochondrial and death receptor pathways in tributyltin-induced apoptosis in rat hepatocytes," Biochimica et Biophysica Acta, vol. 1693, no. 1, pp. 15-27, 2004. 
[38] H. F. Krug, P. C. Klohn, M. Gottlicher, and P. Herrlich, "Alkylated metal compounds mimic signal molecules: the induction of programmed cell death via membrane receptors," Cellular \& Molecular Biology Letters, vol. 6, no. 2A, pp. 406407, 2001.

[39] H. F. Krug, "Metals in clinical medicine: the induction of apoptosis by metal compounds," Materialwissenschaft und Werkstofftechnik, vol. 33, no. 12, pp. 770-774, 2002.

[40] N. N. Danial and S. J. Korsmeyer, "Cell death: critical control points," Cell, vol. 116, no. 2, pp. 205-219, 2004.

[41] F. C. Kischkel, S. Hellbardt, I. Behrmann et al., "Cytotoxicitydependent APO-1 (Fas/CD95)-associated proteins form a death-inducing signaling complex (DISC) with the receptor," The EMBO Journal, vol. 14, no. 22, pp. 5579-5588, 1995.

[42] C. Scaffidi, S. Fulda, A. Srinivasan et al., "Two CD95 (APO1/Fas) signaling pathways," The EMBO Journal, vol. 17, no. 6, pp. 1675-1687, 1998.

[43] S. C. Chow and S. Orrenius, "Rapid cytoskeleton modification in thymocytes induced by the immunotoxicant tributyltin," Toxicology and Applied Pharmacology, vol. 127, no. 1, pp. 1926, 1994.

[44] V. Gogvadze, H. Stridh, S. Orrenius, and I. Cotgreave, "Tributyltin causes cytochrome $\mathrm{c}$ release from isolated mitochondria by two discrete mechanisms," Biochemical and Biophysical Research Communications, vol. 292, no. 4, pp. 904-908, 2002.

[45] J. Zhang, Z. Zuo, Y. Wang, A. Yu, Y. Chen, and C. Wang, "Tributyltin chloride results in dorsal curvature in embryo development of Sebastiscus marmoratus via apoptosis pathway," Chemosphere, vol. 82, no. 3, pp. 437-442, 2011.

[46] C. Fumarola and G. G. Guidotti, "Stress-induced apoptosis: toward a symmetry with receptor-mediated cell death," Apoptosis, vol. 9, no. 1, pp. 77-82, 2004.

[47] A. Nopp, J. Lundahl, and H. Stridh, "Caspase activation in the absence of mitochondrial changes in granulocyte apoptosis," Clinical and Experimental Immunology, vol. 128, no. 2, pp. 267-274, 2002.

[48] C. Oberle, U. Massing, and H. F. Krug, "On the mechanism of alkylphosphocholine (APC)-induced apoptosis in tumour cells," Biological Chemistry, vol. 386, no. 3, pp. 237-245, 2005.

[49] S. R. Pheng, S. Chakrabarti, and L. Lamontagne, "Dosedependent apoptosis induced by low concentrations of methylmercury in murine splenic Fas + T cell subsets," Toxicology, vol. 149, no. 2-3, pp. 115-128, 2000.

[50] F. C. Kischkel, D. A. Lawrence, A. Tinel et al., "Death receptor recruitment of endogenous caspase-10 and apoptosis initiation in the absence of caspase-8," The Journal of Biological Chemistry, vol. 276, no. 49, pp. 46639-46646, 2001.

[51] M. R. Sprick, E. Rieser, H. Stahl, A. Grosse-Wilde, M. A. Weigand, and H. Walczak, "Caspase-10 is recruited to and activated at the native TRAIL and CD95 death-inducing signalling complexes in a FADD-dependent manner but can not functionally substitute caspase-8," The EMBO Journal, vol. 21, no. 17, pp. 4520-4530, 2002.

[52] L. Meng, K. Sefah, M. B. O’Donoghue et al., "Silencing of PTK7 in colon cancer cells: caspase-10-dependent apoptosis via mitochondrial pathway," PLoS One, vol. 5, no. 11, Article ID e14018, 2010.

[53] D. M. Conrad, S. J. Furlong, C. D. Doucette, K. A. West, and D. W. Hoskin, "The $\mathrm{Ca}^{2+}$ channel blocker flunarizine induces caspase-10-dependent apoptosis in Jurkat T-leukemia cells," Apoptosis, vol. 15, no. 5, pp. 597-607, 2010.

[54] K. Wachmann, C. Pop, B. J. van Raam et al., "Activation and specificity of human caspase-10," Biochemistry, vol. 49, no. 38, pp. 8307-8315, 2010.
[55] M. Leist and M. Jäättelä, "Four deaths and a funeral: from caspases to alternative mechanisms," Nature Reviews Molecular Cell Biology, vol. 2, no. 8, pp. 589-598, 2001.

[56] M. Leist and M. Jäättelä, "Triggering of apoptosis by cathepsins," Cell Death and Differentiation, vol. 8, no. 4, pp. 324-326, 2001.

[57] L. E. Bröker, F. A. E. Kruyt, and G. Giaccone, "Cell death independent of caspases: a review," Clinical Cancer Research, vol. 11, no. 9, pp. 3155-3162, 2005.

[58] R. H. H. Pieters, M. Bol, B. W. Lam, W. Seinen, and A. H. Penninks, "The organotin-induced thymus atrophy, characterized by depletion of $\mathrm{CD} 4^{+} \mathrm{CD} 8^{+}$thymocytes, is preceded by a reduction of the immature $\mathrm{CD} 4^{-} \mathrm{CD} 8^{+} \mathrm{TcR} \alpha \beta^{- \text {low }} \mathrm{CD} 2^{\text {high }}$ thymoblast subset," Immunology, vol. 76, no. 2, pp. 203-208, 1992.

[59] R. S. Anderson, M. A. Unger, and E. M. Burreson, "Enhancement of Perkinsus marinus disease progression in TBTexposed oysters (Crassostrea virginica)," Marine Environmental Research, vol. 42, no. 1-4, pp. 177-180, 1996.

[60] E. L. Cooper, V. Arizza, M. Cammarata, L. Pellerito, and N. Parrinello, "Tributyltin affects phagocytic activity of Ciona intestinalis hemocytes," Comparative Biochemistry and Physiology Part C, vol. 112, no. 3, pp. 285-289, 1995.

[61] H. J. Schuurman, H. van Loveren, J. Rozing, and J. G. Vos, "Chemicals trophic for the thymus: risk for immunodeficiency and autoimmunity," International Journal of Immunopharmacology, vol. 14, no. 3, pp. 369-375, 1992.

[62] J. G. Vos, A. De Klerk, E. I. Krajnc, H. van Loveren, and J. Rozing, "Immunotoxicity of bis(tri-n-butyltin)oxide in the rat: effects on thymus-dependent immunity and on nonspecific resistance following long-term exposure in young versus aged rats," Toxicology and Applied Pharmacology, vol. 105, no. 1, pp. 144-155, 1990.

[63] M. M. Whalen, S. A. Green, and B. G. Loganathan, "Brief butyltin exposure induces irreversible inhibition of the cytotoxic function on human natural killer cells, in vitro," Environmental Research, vol. 88, no. 1, pp. 19-29, 2002.

[64] M. A. Champ, "A review of organotin regulatory strategies, pending actions, related costs and benefits," Science of the Total Environment, vol. 258, no. 1-2, pp. 21-71, 2000.

[65] Commission Decision, "Council Directive 76/769/EEC regarding restrictions on the marketing and use of organostannic compounds," 2009, http://eur-lex.europa.eu/LexUriServ/ LexUriServ.do?uri=OJ:L:2009:138:0011:0013:EN:PDF. 

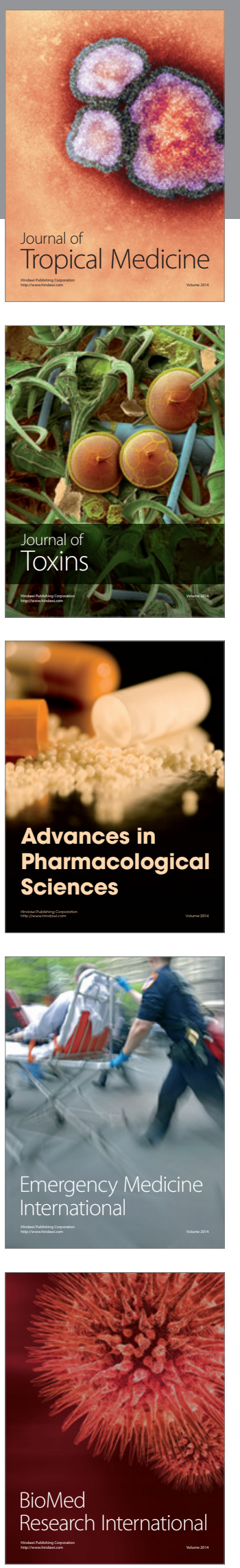
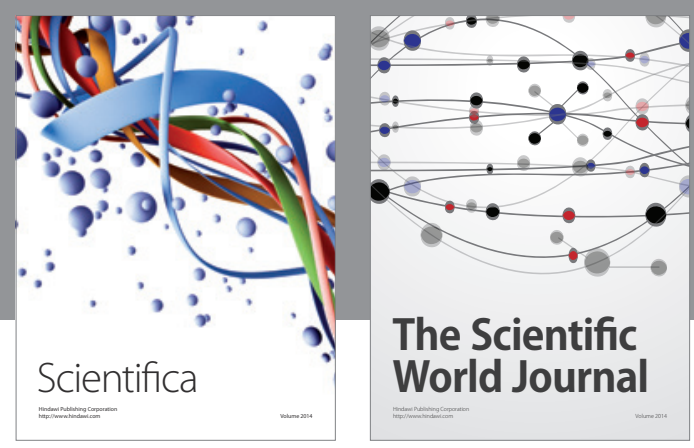

The Scientific World Journal
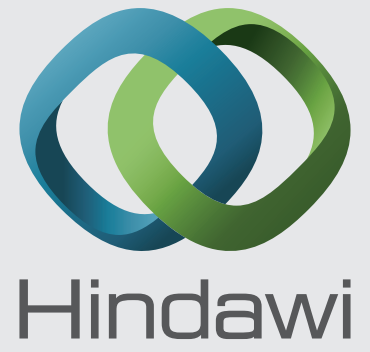

Submit your manuscripts at

http://www.hindawi.com
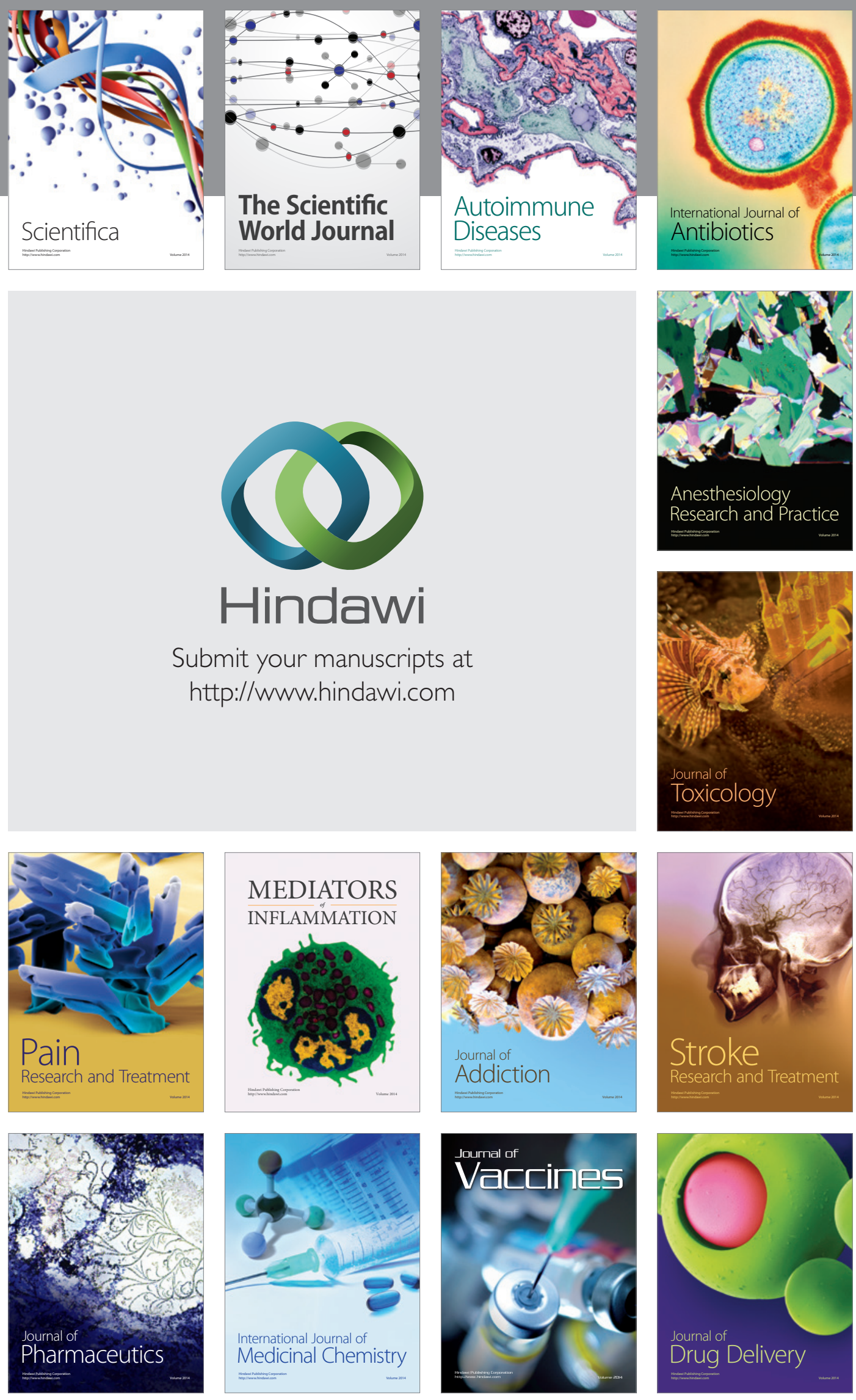